\title{
PENDIDIKAN KESEHATAN TENTANG HIPERTENSI DAN PELATIHAN PENATALAKSANAAN HENTI JANTUNG PADA LANSIA DI PERSATUAN PURNABAKTI LOGISTIK
}

\author{
Sri Haryuni ${ }^{1}$ ) Dessy Lutfiasari ${ }^{2}$ ) \\ Fakultas Ilmu Kesehatan, Universitas Kadiri \\ ${ }^{1}$ sri.haryuni@unik-kediri.ac.id \\ ${ }^{2}$ dessylutfiasari@unik-kediri.ac.id
}

\begin{abstract}
ABSTRAK
Hipertensi merupakan penyakit yang menjadi penyebab kematian tertinggi di dunia. Salah satu komplikasi dari hipertensi diantaranya adalah henti jantung yang dapat menyebabkan kematian mendadak. Prevalensi kejadian hipertensi dan henti jantung tertinggi pada lansia dan kebanyakan tidak disadari oleh penderita. Sasaran pengabdian masyarakat ini adalah lansia di paguyuban Purnabakti Logistik Kota Kediri. Para lansia diberikan pendidikan kesehatan tentang hipertensi dan penanganannya serta diberikan pelatihan penatalaksanaan henti jantung. Hasil kegiatan menunjukkan terjadinya peningkatan pengetahuan tentang hipertensi dan penatalaksanaanya dari $62,5 \%$ menjadi $90,6 \%$. Kegiatan kedua berupa pelatihan penanganan henti jantung didapatkan ketrampilan setelah pelatihan $87,5 \%$. Dengan demikian dapat disimpulkan bahwa pemberian pendidikan kesehatan dan pelatihan dapat meningkatkan pengetahuan serta ketrampilan tentang penatalaksanaan hipertensi dan penanganan henti jantung.
\end{abstract}

Kata Kunci : Hipertensi, henti jantung, pendidikan kesehatan, pelatihan

\section{PENDAHULUAN}

Hipertensi bukan hanya penyakit yang sering menyebabkan kematian tetapi juga menjadi penyebab tertinggi kematian di dunia. Hipertensi juga menjadi penyakit ancaman dalam hidup manusia dimana terdapat modifikasi faktor resiko dari hipertensi. (Zeng et al, 2011). Shen (2017) dalam penelitiannya menyatakan bahwa wanita yang mengalami menopause dini (usia $<45$ tahun) di Cina mempunyai prevalensi yang tinggi terjadinya penyakit jantung koroner dan stroke.

Di Indonesia, mencapai 17-21\% dari populasi penduduk kebanyakan tidak terdeteksi. $60 \%$ penderita hipertensi berakhir pada stroke. Diperkirakan penderita hipertensi di Indonesia mencapai 15 juta jiwa tetapi hanya 4\% yang merupakan hipertensi terkontrol. Prevalensi 6-15\% pada orang lanjut usia, 50\% tidak menyadari sebagai penderita hipertensi sehingga mereka cenderung menjadi 
hipertensi berat karena tidak menghindari dan tidak mengetahui faktor resikonya, dan 90\% merupakan hipertensi esensial. (Tjandra, 2013). Hasil survey yang dilakukan di Paguyuban Purnabakti Logistik Kota Kediri didapatkan 2 (6,25\%) orang pernah mengalami stroke akibat hipertensi, sedangkan penderita hipertensi ditemukan 19 orang $(59,4 \%)$ dari 32 orang. Hal ini menunjukkan masih tingginya penderita hipertensi di paguyuban purnabakti logistik Kota Kediri.

Beberapa faktor penyebab hipertensi diantaranya adalah umur, jenis kelamin, riwayat keluarga, ras, obesitas, obat - obatan, sensitivitas natrium, dan kadar kalium rendah. Konsumsi makanan yang mengandung asam amino esensial yang tinggi seperti kacang kacangan juga akan meningkatkan resiko hipertensi (Teymori, 2018). Jika hipertensi tidak segera ditangani maka dapat menimbulkan sakit kepala, sering merasa pusing yang terkadang dirasakan sangat berat, nyeri perut, muntah, anoreksia, gelisah, berat badan turun, keluar keringat secara berlebihan (Kuswardhani, 2007). Lebih jauh lagi akan terjadi komplikasi pada organ tubuh seperti komplikasi pada otak, komplikasi pada mata, komplikasi pada jantung, dan komplikasi pada ginjal (Herlambang, 2012).

Melihat komplikasi yang terjadi pada penderita hipertensi maka perlu dilakukan pendidikan kesehatan tentang penatalaksanaan hipertensi serta perlunya diberikan pelatihan tentang pertolongan pertama terhadap henti jantung sebagai akibat dari hipertensi. Menurut hasil penelitian, buah dan sayur merupakan komponen penting dari diet secara tradisional dimana buah dan sayur kaya akan nutrisi seperti serat, vitamin dan mineral yang mempunyai manfaat untuk kesehatan jantung (Papadaki, 2018). Konsumsi buah empat kali sehari atau lebih akan menurunkan resiko kejadian hipertensi. (Jiwon, 2017). Buah papaya dan buah semangka dapat dijadikan sebagai salah satu alternative pengobatan alamiah untuk menurunkan hipertensi sehingga dapat terhindar dari komplikasi akibat hipertensi (Lutfiasari, 2017).

Berdasarkan latar belakang diatas maka perlu diberikannya pendidikan kesehatan dan pelatihan penatalaksanaan henti jantung terutama pada lansia sebagai bentuk antisipasi terhadap maraknya penyakit degeneratif pada lansia terutama hipertensi dan komplikasinya. 


\section{METODE PELAKSANAAN}

Kegiatan pengabdian masyarakat ini dilaksanakan mulai tanggal 26 Februari sampai 10 Maret 2018 (2 minggu) bertempat di Aula BULOG Kota Kediri. Jumlah sasaran pengabdian masyarakat yaitu 32 orang anggota dan pengurus Paguyuban purnabakti Logistik Kota Kediri.

Alat dan bahan yang digunakan antara lain :

1. Laptop

2. LCD Projector

3. Phantom RJP

4. Tensimeter

5. Stetoscope

6. Booklet penanganan hipertensi

Prosedur kerja digambarkan dalam gambar berikut ini

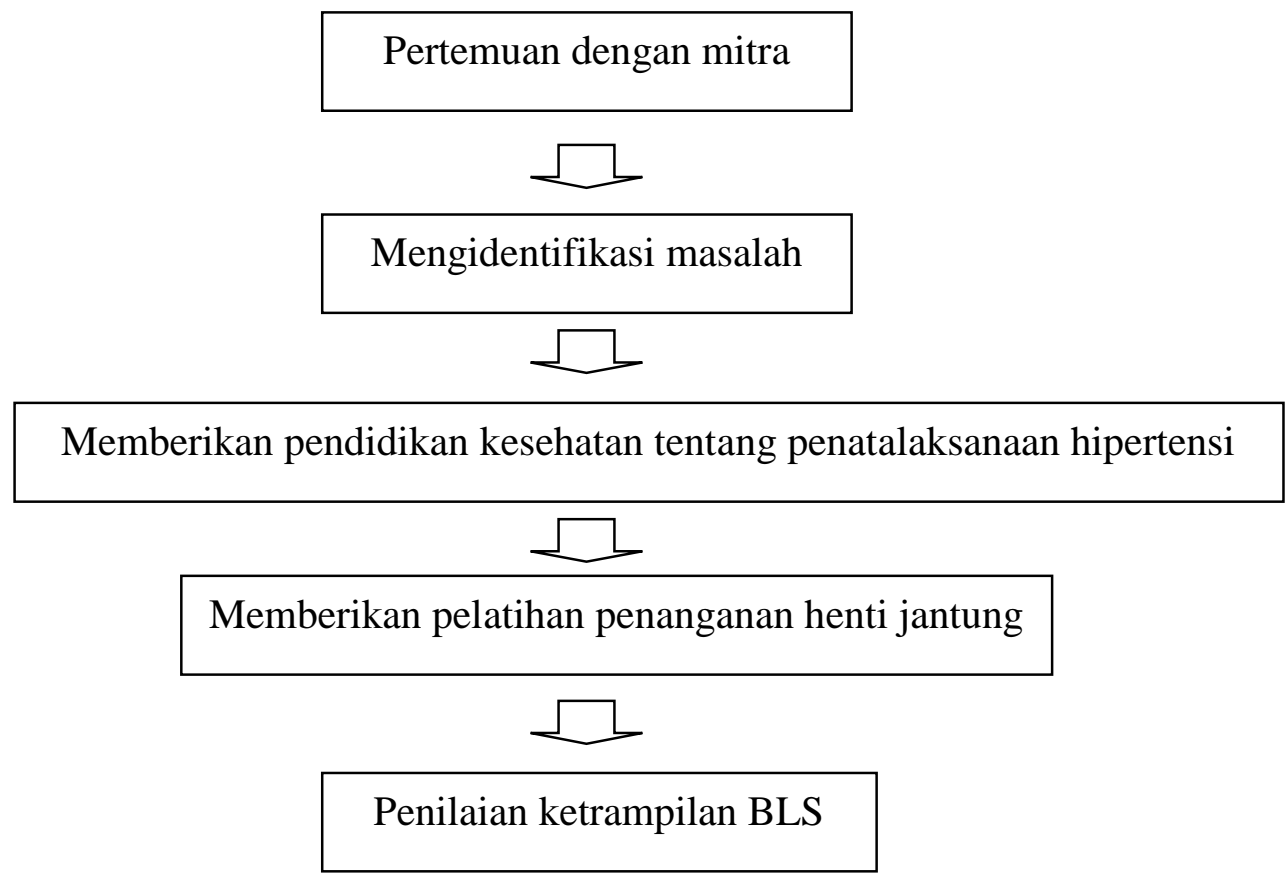

\section{HASIL DAN PEMBAHASAN}

Kegiatan pengabdian masyarakat diawali dengan identifikasi masalah yang terjadi di Paguyuban Purnabakti Logistik Kota Kediri. Dari 32 orang lansia didapatkan 2 orang menderita stroke, 19 orang menderita hipertensi dan 2 orang 
diantaranya disertai dengan diabetes mellitus. Sebaran penyakit yang diderita lansia di Paguyuban Purnabakti Logistik Kota Kediri dapat dilital pada tabel 1 berikut ini.

Tabel 1 Distribusi Penyakit yang diderita Lansia

\begin{tabular}{llll}
\hline No & Penyakit yang diderita & Frekuensi & Prosentase \\
\hline 1 & Stroke & 2 & 6,25 \\
2 & Hipertensi & 19 & 59,38 \\
3 & Diabetes Melitus & 2 & 6,25 \\
4 & Jantung & 5 & 15,6 \\
5 & Tidak menderita penyakit & 4 & 12,5 \\
\hline & Total & 32 & 100 \\
\hline
\end{tabular}

Data menunjukkan bahwa masih tingginya lansia yang mengalami hipertensi. Hipertensi tidak dapat disembuhkan secara langsung sehingga perlu dilakukan pengukuran yang terus menerus. Sehingga pengukuran tekanan darah yang dilakukan secara kontinyu dapat menjadi bahan screening awal timbulnya hipertensi terutama pada lansia (Charles, 2016).

Kegiatan pertama yaitu dilakukan pretest tentang pengetahuan hipertensi dan penatalaksanaannya didapatkan 20 (62,5\%) mengetahui tentang penatalaksanaan hipertensi dan henti jantung. Langkah kedua setelah identifikasi masalah diberikan pendidikan kesehatan tentang hipertensi dan penatalaksanaannya. Kegiatan tersebut tergambar dalam gambar 1 dan 2.

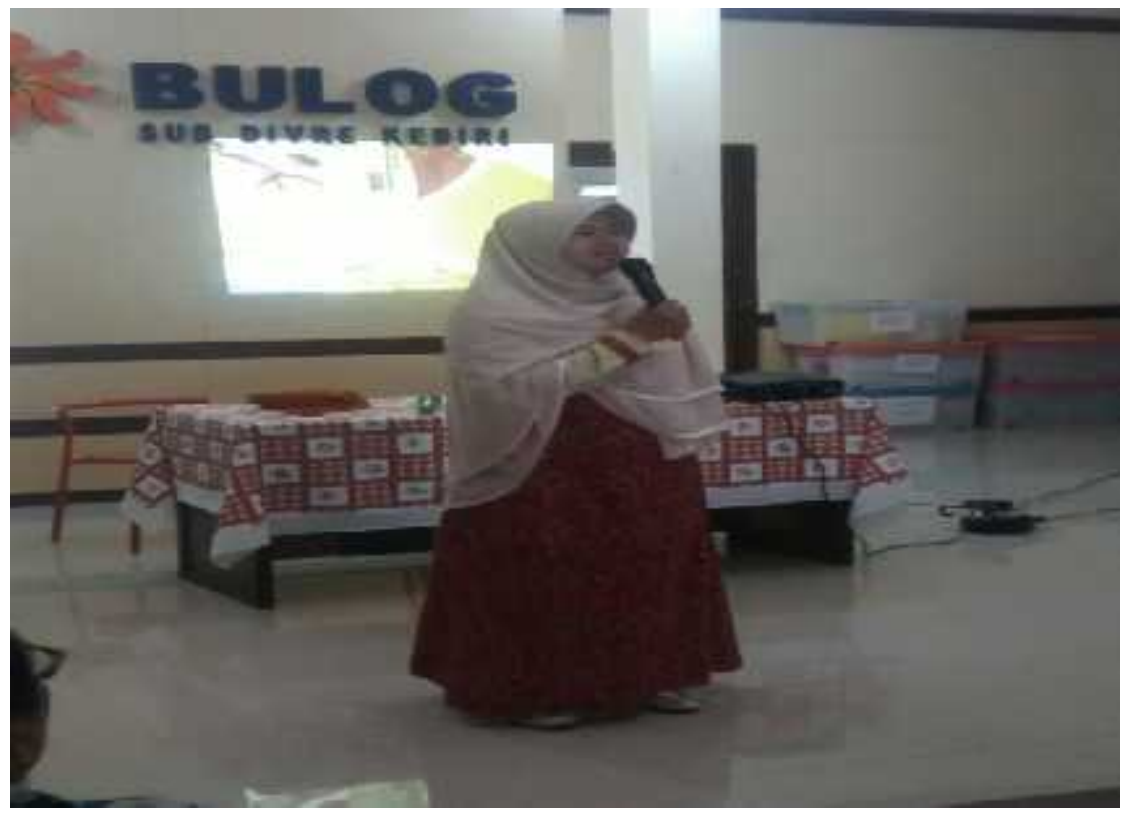

Gambar 1 Pendidikan Kesehatan tentang Hipertensi 


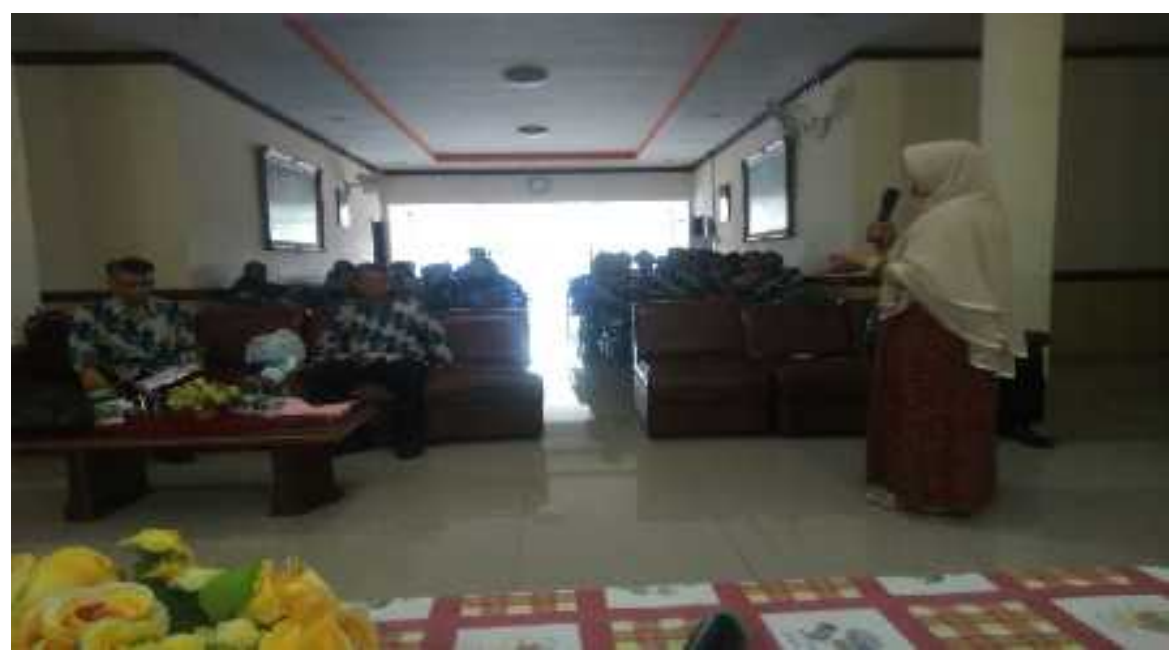

Gambar 2 Pendidikan Kesehatan tentang Penatalaksanaan Hipertensi

Setelah pemberian pendidikan kesehatan tentang hipertensi dan penatalaksanaannya, kemudian dilakukan evaluasi terhadap pengetahuan lansia. Hasil yang didapatkan 29 orang $(90,6 \%)$ mengerti tentang hipertensi dan penatalaksanaannya. Terjadi peningkatan pengetahuan setelah dilakukan pendidikan kesehatan. Hal ini sejalan dengan kegiatan pengadian masyarakat yang dilakukan oleh Sudarsono, dkk (2017) bahwa terjadi peningkatan pengetahun tentang hipertensi pada anak muda setelah dilakukan edukasi tentang hipertensi dengan menggunakan media audio.

Sebagai antisipasi terhadap komplikasi yang terjadi pada hipertensi yaitu henti jantung, maka diberikan pelatihan tentang penatalaksanaan henti jantung. Kegiatan tersebut diakhiri dengan penilaian ketrampilan tata laksana henti jantung pada orang awam. Hasil yang didapatkan dari penilaian ketrampilan penanganan henti jantung pada orang awam yaitu sebagian besar (87,5\%) mampu melakukan penatalaksanaan henti jantung. Hal ini sejalan dengan penelitian yang dilakukan Haryuni (2017) bahwa kegiatan pelatihan penanganan henti jantung terutama dengan metode demontrasi lebih efektif dalam meningkatkan kemampuan life saving. Kegiatan tersebut dapat dilihat dalam gambar 3 dan gambar 4. 


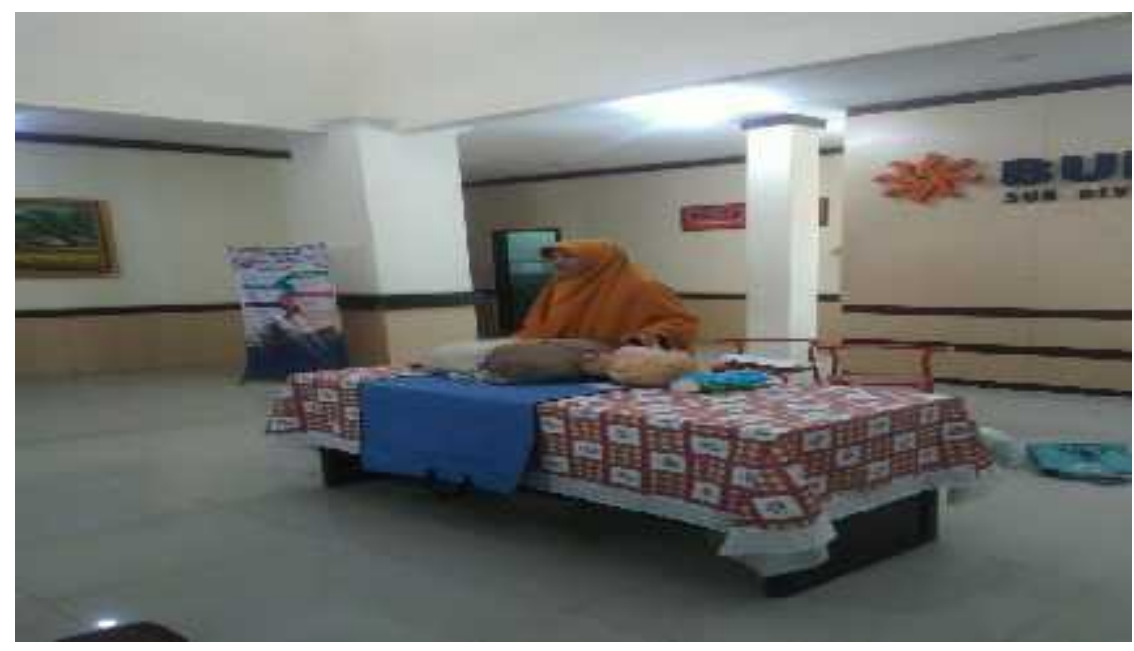

Gambar 3 Pelatihan tata laksana henti jantung untuk awam

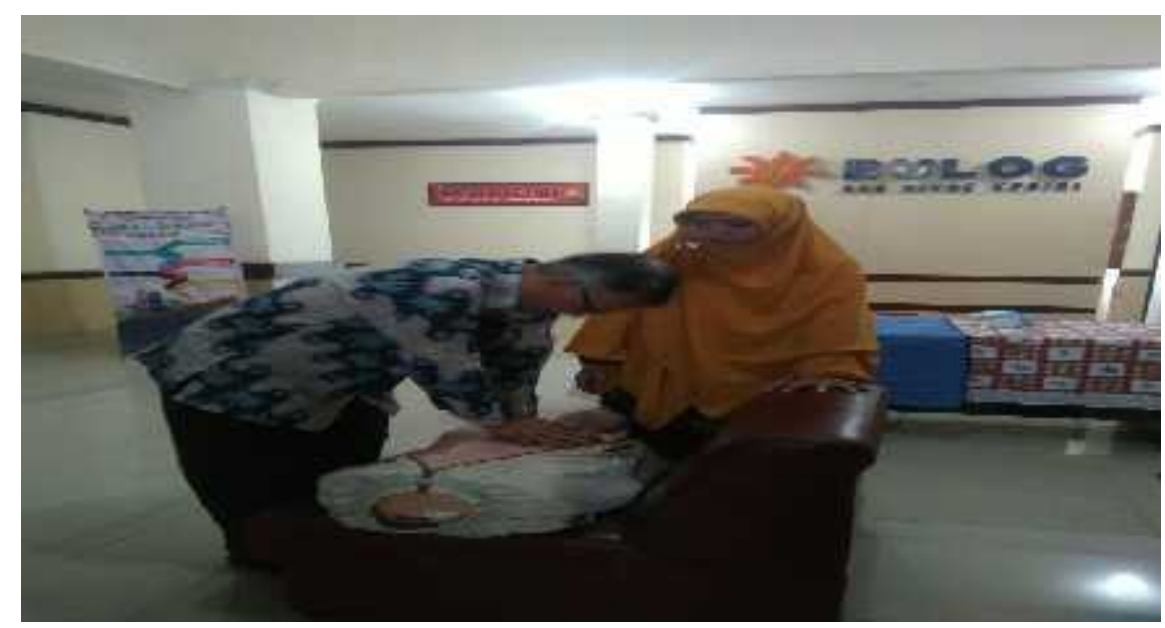

Gambar 4 Evaluasi Ketrampilan tata laksana henti jantung untuk awam

Kegiatan pengabdian masyarakat pada kelompok resiko tinggi yaitu lansia berupa edukasi dan pelatihan kesehatan di Paguyuban Purnabakti Logistik Kota Kediri belum pernah dilakukan sebelumnya. Hal ini dikarenakan minimnya kerjasama paguyuban dengan institusi kesehatan yang melaksanakan kegiatan pengabdian masyarakat. Dengan adanya kegiatan pengabdian masyarakat ini pengurus maupun anggota merasa senang dan terbantu, terlebih lagi peserta dibagikan booklet resep penurunan tekanan darah pada hipertensi menggunakan buah dan sayur. Dengan adanya pemberian edukasi dan pelatihan penatalaksanaan henti jantung pada lansia diharapkan lansia dapat meningkatkan daya diri untuk 
meningkatkan kesehatan dirinya serta mempunyai bekal pertolongan pertama terhadap henti jantung jika sewaktu waktu terjadi pada kelompoknya.

\section{SIMPULAN}

Adanya peningkatan pengetahuan tentang hipertensi dan penatalaksanaannya dari $62,5 \%$ menjadi $90,6 \%$ mengetahui tentang hipertensi dan penatalaksanaannya. Sedangkan ketrampilan penanganan henti jantung pada awam didapatkan 87,5\% mampu melaksanakan penanganan henti jantung.

\section{DAFTAR PUSTAKA}

Charles A.S, dkk. 2016. Pemeriksaan Kadar Kolesterol dan Tekanan Darah pada Masyarakat Kota Jambi sebagai Skrining Awal Penyakit Jantung Koroner. Jurnal Pengabdian pada Masyarakat Universitas Jambi volume 31 nomor 4 Oktober-Desember 2016.

Haryuni, Sri. Sulistyo, Wiwin. 2017. Perbedaan Efektifitas Metode Pendidikan Kesehatan Basic Life Support (BLS) Audiovisual dengan Demonstrasi terhadap Kemampuan Life Saving pada mahasiswa Ilmu Keperawatan FIK Universitas Kadiri. Journal Nursing care and Biomolecular vol. 2 no.1 Juni 2017. ISSN 2548-6802

Herlambang, 2012. Hipertensi: Merawat dan Menyembuhkan Penyakit Darah Tinggi. Bantul: Kreasi Wacana.

Jiwon Kim, et al. 2017. Association between Fruit and Vegetables Consumption and Risk of Hypertension in Middle Age and Older Korea Adult. Journal of The Academy of Nutrition and Dietetics vol. 12 no.4 ISSN 2212-2672

Kuswardhani, 2007. Hipertensi pada Usia Lanjut. Yogyakarta : CV. Vita

Lutfiasari, Dessy. 2017. Perbedaan Efektifatas Pemberian Jus Pepaya dengan Jus Semengka terhadap Perubahan Tekanan Darah pada Wanita Menopause dengan Hipertensi. Jurnal penelitian Keperawatan volume 3 no. 2 Agustus 2017 ISSN 2407-7232

Papadaki, Angeliki. 2018. The Prevention of Cardiovaskular Disease Through The Mediteranian Diet. Chapter 6 : Fruit and Vegetables. Academic Press pages 101-109 
Shen, Lijun et al. 2017. Effect of Early Age at Natural Menopause on Coronary Heart Disease and Stroke in Chinese Woman. International Journal $\mathrm{f}$ Cardiology volume 24115 Agustus 2017 pages 6-11

Sudarsono, Erica Kusuma Rahayu. 2017. Peningkatan Pengetahuan tentang Hipertensi Guna Perbaikan Tekanan Darah pada Anak Muda di Dusun Japanan, Margodadi, Sayegan, Sleman, Yogyakarta. JPKM vol. 3 no. 1 September 2013 hal 26-38. DOI:http://doi.org/10.22146/jpkm.23286 ISSN 2460-9447 (Print), 2541-5883(online) di http://jurnal.ugm.ac.id/jpkm

Teymori, Farshad. 2018. High Dietary Intake of Aromatic Amino Acids Increase Risk of Hypertension. Journal of The American Society of Hypertension volume 12 Issue 1 January 2018 pages $25-33$

Tjandra, 2013. Riset Kesehatan Dasar. Jakarta: Depkes RI

Zeng, Ya Weng, et al. 2011. Strategies of Functional Food for Hypertension Prevention in China. Journal of Medicinal Plant Research vo. 5 (24) pp. 5671-5676. 30 Okt 2011. ISSN 1996-0875 